\title{
Uma tentativa de comparação entre as personagens Luís Padilha, de S. Bernardo, de Graciliano Ramos, e Iago, de Otelo, de William Shakespeare
}

Octávio Henrique Chames dos Santos ${ }^{\mathrm{i}}$

\begin{abstract}
RESUMO
O crítico Juarez Filho (2006) questiona a veracidade do relato de Paulo Honório, narrador-protagonista de S. Bernardo, de Graciliano Ramos (1934). A partir disso, indaga "quem teria sido o Iago em São Bernardo?", referindo-se ao personagem shakespeariano da tragédia Otelo (1606). Neste artigo, propomos, então, uma resposta a essa provocação. Baseando-nos nas características atribuídas a Iago por críticos como Bloom (1998) e no exame de excertos de Otelo e de S. Bernardo, buscamos sustentar que o ex-proprietário da fazenda S. Bernardo, Luís Padilha, assume esse papel.
\end{abstract}

Palavras-chave: Graciliano Ramos; Otelo; S. Bernardo; William Shakespeare.

\begin{abstract}
The critic Juarez Filho (2006) questions the veracity of Paulo Honório's account, the narrator and protagonist from the book S. Bernardo, by Graciliano Ramos (1934). From this, he asks "who would have been Iago in São Bernardo?", referring to the Shakespearean character from the tragedy Othello (1606). In this article, we propose an answer to this provocation. Based on the characteristics attributed to Iago by critics such as Bloom (1998) and on the examination of excerpts from Othello and S. Bernardo, we seek to maintain that the former owner of the S. Bernardo farm, Luís Padilha, takes on that role.
\end{abstract}

Keywords: Graciliano Ramos; Othello; S. Bernardo; William Shakespeare.

\footnotetext{
${ }^{i}$ Graduado em Letras - Português/Inglês pelo Centro Universitário Anhanguera de Pirassununga/SP. Mestrando em Letras pela UNESP/IBILCE. Bolsista de Mestrado do CNPq.

E-mail: octaviohenrique994@gmail.com
} 


\section{INTRODUÇÃO}

Em determinada altura de sua dissertação de mestrado, Edmundo Juarez Filho lança uma interessante provocação sobre o romance S. Bernardo, de Graciliano Ramos (2018). Baseando-se nas considerações críticas de Lorençato (1995), Juarez Filho (2006) visualiza uma referência à tragédia shakespeariana Otelo (2017) na cena em que uma folha de papel vem parar nas mãos de Paulo Honório, na véspera do suicídio de Madalena. Segundo Lorençato (1995, p. 112), "a carta a um homem tem a força do lenço que Iago inventa que Desdêmona entregou ao amante". Nesse sentido, o crítico lança a indagação: “quem teria sido o Iago em São Bernardo?” (JUAREZ FILHO, 2006, p. 89).

A nosso ver, uma comparação entre S. Bernardo e Otelo parece viável, afinal, em ambas as obras, há uma personagem masculina dominadora que sucumbe ao ciúme e destrói a própria vida depois de levar a mulher amada à morte. Enquanto Otelo literalmente asfixia Desdêmona, poderíamos sustentar que Paulo Honório, com um ciúme implacável e sua brutalidade habitual contra todos, também asfixia Madalena, em sentido figurado, induzindo-a ao suicídio. No caso da tragédia shakespeariana, é amplamente reconhecido que Otelo só acaba se deixando tomar pelo ciúme por causa de Iago, seu alferes, responsável por semear várias dúvidas quanto à fidelidade de Desdêmona na mente do mouro. Por outro lado, a influência de outra personagem não é tão evidente no caso de Paulo Honório. A crítica especializada geralmente atribui o surgimento do ciúme do coronel exclusivamente ao que autores como Antonio Candido (1992) denominam de sentimento de propriedade, isto é, um desejo intenso de posse que levaria o protagonista a enxergar as relações humanas da seguinte maneira: "O próximo lhe interessa na medida em que está ligado aos seus negócios, e na ética dos números não há lugar para o luxo do desinteresse" (CANDIDO, 1992, p. 25). Todavia, esse desejo de posse não se restringe a bens materiais ou, mais especificamente, à fazenda S. Bernardo. Como Lafetá (1995) sustenta, também Madalena é alvo desse sentimento de propriedade. Inclusive, seria ela a responsável pela mudança de tom do narrador depois do nono capítulo, quando é mencionada pela primeira vez em uma conversa entre os amigos de Paulo Honório. De acordo com Lafetá: 
Depois da posse de S. Bernardo vem a posse de Madalena. Ultrapassada a
unidade que se formara em torno da relação entre Paulo Honório e a
propriedade, um outro núcleo começa a se esboçar. O capítulo nono entretece
alguns motivos novos - e o leitor percebe que o romance vai ganhar rumo
diferente. O estilo se distende um pouco, a tensão arrefece. A preferência do
narrador volta-se agora para a técnica da cena, e surgem os detalhes
concretos, as caracterizações mais alongadas dos personagens, os diálogos
miúdos sobre assuntos do dia-a-dia. O tom compacto se esgarça de leve e a
narrativa salta de um tema para outro. (LAFETÁ, 1995, p. 200, grifos
nossos)

Porém, Madalena se recusa a aderir à visão de mundo do protagonista, optando pelo humanitarismo em detrimento do sentimento de propriedade. Segundo Candido (1992), inicia-se, a partir desse momento, um conflito na mente do coronel de S. Bernardo entre a bondade de Madalena e seu instinto de posse. Infelizmente, o ciúme surgiria como resultado desse conflito:

Até então, ninguém fazia sombra a Paulo Honório; agora, eis que alguém vai
destruindo a sua soberania; alguém brotado da necessidade patriarcal de
preservar a propriedade no tempo, e que ameaça perdê-la. O senhor de São
Bernardo reage pelo ciúme, expansão natural do seu temperamento forte e
forma, ora disfarçada, ora ostensiva, do mesmo senso de exclusivismo que o
dirige na posse dos bens materiais. Ciúme que aparece, às vezes, como eco
de costumes primitivos, de velhos raptos tribais, de casamentos por compra
fervendo no sangue. (CANDIDO, 1992, p. 27 , grifos nossos)

A hipótese de que o ciúme de Paulo Honório proviria do sentimento de propriedade é bastante coerente com o que se lê no romance. Para confirmar isso, podemos citar o capítulo XXI, quando o coronel desconta no empregado Marciano sua frustração com os gastos de Madalena com a escola da fazenda: "O que agora me importunava eram as caixas com o material pedagógico inútil nestes cafundós. Para que aquilo? O governador se contentaria se a escola produzisse alguns indivíduos capazes de tirar o título de eleitor" (RAMOS, 2018, p. 127). Em uma leitura mais rasa, poder-se-ia dizer que a frustração do coronel advém de a esposa ter-lhe imposto uma "despesa supérflua”. No entanto, se nos atentarmos à função da escola segundo Paulo Honório a de formar eleitores, e não cidadãos -, perceberemos a iniciativa de Madalena como uma ameaça à soberania dele, pois ela pensava em formar cidadãos críticos, e não eleitores acríticos. Se unirmos isso à "confissão" de Paulo Honório no capítulo XII do romance sobre como estimulava a produtividade na fazenda, ficará ainda mais claro que a cólera do coronel pode ter outra motivação: “[...] é bom um cidadão pensar que tem influência no governo, embora não tenha nenhuma. Lá na fazenda o trabalhador mais 
desgraçado está convencido de que, se deixar a peroba, o serviço emperra. Eu cultivo a ilusão. E todos se interessam" (RAMOS, 2018, p. 77).

O sentimento de propriedade não é necessariamente a única fonte do ciúme do coronel, assim como, inversamente, em Otelo, o ciúme não surge apenas por causa das artimanhas de Iago contra o mouro de Veneza. Na verdade, o alferes só teria manipulado a percepção de seu chefe sobre Desdêmona porque Otelo teria um sentimento de inferioridade em relação à esposa e ao suposto amante dela, o tenente Cássio, como afirma Polidório (2013):

\begin{abstract}
Otelo é útil para o Estado, é por isso que ele é enviado para Chipre e seu casamento com Desdêmona não desperta a ira do Duke. Como herói trágico, ele tem que ser uma pessoa importante. Porém, sua importância se refere somente a seus serviços de grande guerreiro. O ciúme desmedido cega Otelo, porém, esse ciúme somente é possível porque ele se sente inferior a Cássio e à própria Desdêmona. [...] A necessidade de termos um Otelo que trazia somente atributos de um guerreiro, e não de um cavalheiro, foi essencial para a sua derrocada. (POLIDÓRIO, 2013, p. 229, grifos do autor)
\end{abstract}

Neste artigo, portanto, procuraremos responder à provocação de Juarez Filho (2006) quando compara sucintamente S. Bernardo (1934), de Graciliano Ramos, com Otelo (1606), de William Shakespeare. Vale registrar que o crítico especula dois possíveis candidatos ao posto de Iago em S. Bernardo: primeiro, o jornalista Azevedo Gondim que, no capítulo XVI, "força" Paulo Honório ao casamento ao revelar para Madalena que a união entre o coronel e a normalista era conversa de toda a cidade; segundo, a própria Madalena, que teria deixado a folha de papel voar de propósito para o marido "matá-la" de vez. Não seguiremos por esses caminhos, pois não encontramos evidências suficientes no romance para acusá-los, nem motivações palpáveis para Gondim ou Madalena desejarem a queda do coronel derrotado tal qual Iago queria a de seu chefe. Nossa tentativa de comparação, na verdade, será com quem traiu Paulo Honório ao final do romance e teria motivos para querer vingança: Luís Padilha, o exproprietário de S. Bernardo, de quem Paulo Honório “compra"/toma a fazenda no capítulo IV.

Dividiremos nossas reflexões em três partes. Primeiro, caracterizaremos Iago e procuraremos evidenciar suas razões para querer a destruição de Otelo. Em seguida, analisaremos Luís Padilha e levantaremos hipóteses para seu possível desejo de vingança. Por fim, traçaremos analogias entre os comportamentos e as trajetórias de Iago na tragédia shakespeariana e de Luís Padilha no romance graciliânico. 


\title{
QUEM É IAGO EM OTELO?
}

Segundo o crítico estadunidense Harold Bloom, "nenhum vilão em toda a literatura rivaliza com Iago como uma concepção perfeita, que não requer melhoramentos"1 (BLOOM, 1998, p. 453). A trajetória dessa personagem pode ser sintetizada da seguinte maneira: alferes de Otelo, Iago é preterido em uma promoção a tenente em favor de Cássio Miguel. Após isso, de leal servidor do mouro de Veneza, o alferes passa a odiá-lo, se aliando a um ex-pretendente de Desdêmona, Rodrigo, com o intuito de destruir seu chefe. Ainda no início do primeiro ato, ao ser interpelado pelo aliado sobre o porquê de ainda se subordinar a Otelo, Iago revela suas razões e explica como será seu modus operandi para destruir o agora rival:

\begin{abstract}
Iago - Ah, meu senhor, não se preocupe. Continuo dele sendo seguidor que é para dar-lhe o troco que merece. [...] Ao ser dele seguidor, estou seguindo apenas a mim mesmo. Os céus podem me julgar: eu não sou eu por amor e dever, mas eu pareço ser eu por causa de meu peculiar propósito. E, quando minhas ações aparentes demonstrarem a verdadeira conduta $e$ os verdadeiros contornos de meu coração em formal expressão de cortesia, não se passará muito tempo e estarei abrindo o meu coração para que os urubus dele façam picadinho... não sou quem eu sou. (SHAKESPEARE, 2017, p. 14-15, grifos nossos)
\end{abstract}

Manipulando tudo e todos (inclusive a própria esposa, Emília), o alferes consegue seu objetivo, pois Otelo asfixia Desdêmona e, posteriormente, comete suicídio. Porém, logo em seguida, Iago é desmascarado por Emília e, condenado à tortura por seus crimes, vê seus planos fracassarem.

Ao longo de seu ensaio sobre tal tragédia shakespeariana, Bloom (1998) compara o alferes de Otelo a diversas outras personagens consideradas, cada uma a seu modo, figurações literárias do mal, como o Satã de Milton e algumas personagens de Dostoiévski. Para Bloom, Iago seria uma espécie de precursor e de influência para essas figuras. Mais especificamente, ele inspiraria personagens ligadas à intelectualidade, a uma visão estética da vida, ao niilismo e ao sadismo. Essas características, aliás, o distinguiriam das outras três grandes personagens masculinas intelectuais de Shakespeare: Hamlet (da tragédia homônima), Edmundo (de Rei Lear) e Falstaff (de diversas peças): 
Os grandes intelectuais masculinos de Shakespeare (em contraste com Rosalinda e Beatriz, entre as mulheres) são apenas quatro no total: Falstaff e Hamlet, Iago e Edmundo. Desses, Hamlet e Iago também são estetas, consciências críticas de poder quase sobrenatural. Apenas em Iago o esteta predomina, em uma aliança muito íntima com o niilismo e o sadismo. (BLOOM, 1998, p. 454) $)^{2}$

Para Bloom, não há questionamento possível quanto ao fato de Iago ser o verdadeiro protagonista de Otelo. O crítico, inclusive, mostra como esse protagonismo se manifesta formalmente na peça: "Não pode haver dúvida quanto à primazia de Iago na peça: ele fala oito solilóquios, Otelo apenas três"3 (BLOOM, 1998, p. 442).

Polidório (2013), por sua vez, propõe a seguinte reflexão quanto à relação de Iago com a linguagem:

O discurso de Iago é muito bem elaborado, ele reflete antes de falar. Ele planeja antes de executar algo, ele tem poder de convencimento, pois sabe usar muito bem a linguagem e escolhe momentos propícios para enganar a todos e para, principalmente, plantar a semente do ciúme em Otelo. (POLIDÓRIO, 2013, p. 226, grifos do autor)

Ou seja, além de ser o protagonista da peça, Iago é bastante hábil na arte do convencimento, utilizando-a para destruir Otelo e todos os outros que se interpõem entre ele e seus objetivos. Isso, até mesmo, motiva Polidório (2013) a caracterizá-lo como um grande manipulador, por ser capaz de encobrir seu caráter sombrio com uma aparência honesta, e a compará-lo a um abutre, por viver esperando a destruição dos outros:

Iago somente serve a Otelo para tirar vantagens. É uma característica da personalidade de Iago, ou seja, o seu poder de fingimento. Com a arte de fingir, Iago consegue enganar a todos. Todos acreditam nele, todos seguem seus conselhos. [...] Iago é o abutre que espreita os moribundos. É a sombra negra que paira sobre os outros personagens. Para ele, nada importa senão a destruição de Otelo e daqueles que o cercam. Ele é um grande manipulador. Ele não mancha suas mãos de sangue. Ele usa os outros personagens como se fossem marionetes. E mesmo assim, todos acham que ele é honesto; está é uma palavra que os outros personagens usam para se referir a Iago. Temos então a aparência versus realidade. (POLIDÓRIO, 2013, p. 227, grifos do autor)

Dezan (2001) também destaca a capacidade de manipulação de Iago, mas concentra-se na estratégia do alferes para destruir o mouro. Segundo o crítico, Otelo encarnaria o conflito entre a ordem e a desordem na tragédia. Inicialmente, por ser um homem da guerra, a personagem viveria uma vida desordenada, sem outro objetivo além de aniquilar os inimigos de Veneza. Com a aparição da bela Desdêmona e do amor entre 
os dois, o mouro perceberia ser possível outro modo de viver. Em outras palavras, Desdêmona seria, nos termos de Dezan, um centro de ordem na vida de seu cônjuge. Com isso, Iago, ao difamar a esposa do inimigo, atacaria a honra do mouro e, principalmente, a possibilidade de harmonia na vida deste. Com esses ataques de Iago, Desdêmona passaria, para Otelo, de pilar da ordem para instigadora da desordem, do caos:

\begin{abstract}
Iago, como raposa astutíssima e leão ardiloso, busca instaurar a desordem na vida de Otelo, ferindo-o em sua honra, pervertendo o amor de Desdêmona. Fá-lo vê-la não como centro ordenador e unificador, mas como princípio de divisão, de tragédia, de morte. A estratégia adotada pelo alferes consiste em destruir a moral de Desdêmona, numa tentativa de reduzi-la a um ser infernal, abjeto e vil. Sob o signo da malícia, Iago induz Otelo a cair em sua armadilha. (DEZAN, 2001, p. 57)
\end{abstract}

O crítico também recorre às obras de Soren Kierkegaard e de Nicolau Maquiavel para rotular o jogo de manipulação de Iago com Otelo como satânico e maquiavélico, frisando a hipocrisia do alferes. Nesse sentido, Dezan (2001) busca mostrar como, além de ser um traço de sua personalidade (ou seja, além de manipulador e fingido, Iago também seria hipócrita), essa hipocrisia faria parte da estratégia para destruir o chefe. Essa máscara hipócrita é tão efetiva para enganar o mouro de Veneza que, em vários momentos, Iago é qualificado como honesto pelo chefe. Essa honestidade, aliás, é a justificativa de Otelo para desconfiar da fidelidade matrimonial de Desdêmona:

\footnotetext{
Otelo - [...] Escutei-te dizer agora mesmo, não gostaste do que viste, quando Cássio despediu-se de minha esposa. Pois não gostaste do quê? [...] Iago - Meu senhor, sabe que lhe tenho amizade profunda.

Otelo - Penso que sim. E, tanto quanto sei, és criatura plena de amor, e honesto, e sabes pesar as palavras antes de dar-lhes vida com teu sopro. Assim é que esse teu vacilar assusta-me ainda mais, pois tal coisa num velhaco falso e desleal é truque costumeiro; mas num homem justo é adiamento em segredo, um mecanismo do coração, coisa sobre a qual a paixão não tem domínio. (SHAKESPEARE, 2017, p. 83-84)
}

Por fim, Dezan (2001) também associa Iago à inveja, pois a felicidade do casal Otelo e Desdêmona, em contraste com a infelicidade de Iago em seu casamento com Emília, seria o inferno para ele. Não divergimos totalmente dessa leitura, mas não usaríamos exatamente "inveja" para descrever o sentimento de Iago. Optamos, na verdade, por um termo de Bloom (1998), já que, a nosso ver, não se trata apenas de inveja, mas, principalmente, de ressentimento. Enfatizando mais uma vez a grande 
capacidade intelectual e a motivação de Iago em seu projeto de destruição, Bloom adverte que

\begin{abstract}
Nós não podemos chegar a uma estimativa justa de Otelo se subestimarmos Iago, que seria formidável o suficiente para destruir a maioria de nós se ele emergisse de sua peça em nossas vidas. Otelo é uma grande alma desesperadamente superada em intelecto e desejo por Iago. [...] O profeta do Ressentimento, Iago prenuncia Smerdiakov, Svidrigailov e Stavrogin em Dostoiévski, assim como todo o espírito ascético deplorado por Nietzsche. (BLOOM, 1998, p. 438)
\end{abstract}

Em suma, do que foi exposto até o momento, podemos caracterizar Iago como fingidor, manipulador, invejoso, maquiavélico e até mesmo satânico. Entretanto, no presente artigo, concentrar-nos-emos em outras duas características atribuídas especificamente por Bloom (1998) ao alferes de Otelo. Depois de ser preterido por Cássio Miguel para o posto de tenente de Otelo, Iago torna-se um intelectual ressentido, e é em um intelectual ressentido, por motivos diferentes da personagem shakespeariana, que vemos um possível "Iago" no romance de Graciliano Ramos. Como dissemos anteriormente, trata-se do ex-proprietário da fazenda de Paulo Honório, Luís Padilha.

\title{
QUEM É LUÍS PADILHA EM S. BERNARDO?
}

A trajetória de Luís Padilha em $S$. Bernardo pode ser sintetizada sem muito esforço. Ele é apresentado no capítulo IV, quando Paulo Honório adquire a fazenda S. Bernardo e começa sua ascensão à condição de mais influente coronel da região. Herdeiro de Salustiano Padilha, Luís volta à propriedade depois de alguns anos na capital estudando Direito. Ele, porém, não havia obtido o diploma, pois, segundo Paulo Honório, concentrava-se mais em diversão do que nos estudos. Ao retornar a S. Bernardo, encontra seu pai no leito de morte e uma propriedade já decadente, pois Salustiano havia envidado todos os seus recursos pelo sonho (frustrado) de ver o filho formado doutor. Após o falecimento do pai, Luís não se dedica à fazenda, mas à boêmia, e Paulo Honório torna-se um de seus credores. Em determinado momento, Honório o convence a tentar reerguer a fazenda, mas o rapaz opta pelos investimentos errados, endivida-se mais ainda com o futuro coronel de S. Bernardo e tem de vender sua herança a um preço relativamente baixo para ele. Alguns capítulos depois, Padilha reaparece e se torna o professor da escola que o coronel construiria na fazenda até a 
"revolução" estourar. Depois disso, se une às forças revolucionárias, coopta alguns funcionários de S. Bernardo no processo e, com isso, trai Paulo Honório.

Em termos de caracterização, tal como Iago em Otelo, Padilha é um intelectual que consegue se valer da linguagem para diversos fins, conhecendo as artimanhas do discurso. Ainda antes de perder a fazenda e de se tornar professor na escola de Paulo Honório, o filho de Salustiano havia fundado uma espécie de jornal local, o Correio de Viçosa. Mesmo depois do jornal ir à falência, continuou a contribuir com contos e artigos para os periódicos locais. Já dando aulas na fazenda, uma discussão sua com Marciano e Casimiro Lopes no capítulo XI também pode ser encarada como uma forma de atuação intelectual politicamente engajada pelo discurso, pois, nesse episódio, Padilha põe em debate a questão do latifúndio e flerta com a reforma agrária (o que causa a ira do patrão). Por último, vale registrar que ele sempre participou das discussões político-partidárias no romance, inclusive a mais decisiva delas, a do capítulo XXIV, quando vem à tona o ciúme do coronel por Madalena.

Em S. Bernardo, Paulo Honório está cercado por intelectuais, entre eles sua esposa. Porém, ao contrário do que acontece em Otelo, nenhuma personagem parece conseguir sobrepujar o coronel, até porque, como afirma Candido (1992), S. Bernardo é um livro "curto, direto e bruto", em que "os personagens e as coisas surgem nele como meras modalidades do narrador, Paulo Honório, ante cuja personalidade dominadora se amesquinham, frágeis e distantes" (CANDIDO, 1992, p. 24). Aliás, mesmo em decadência, Paulo Honório ainda comandava seu jagunço, Casimiro Lopes, assim como exercia influência sobre vários outros empregados da fazenda e, de certa forma, até mesmo sobre o jornalista Azevedo Gondim, o qual, no capítulo I - situado cronologicamente após o suicídio de Madalena e a "revolução" -, adota um tom bastante respeitoso para replicar ao coronel quando este chama os capítulos escritos pelo jornalista de "acanalhados", "pernósticos", "safados" e "idiotas":

- Vá para o inferno, Gondim. Você acanalhou o troço. Está pernóstico, está safado, está idiota. Há lá ninguém que fale dessa forma!

Azevedo Gondim apagou o sorriso, engoliu em seco, apanhou os cacos da sua pequenina vaidade e replicou amuado que um artista não pode escrever como fala $[. .$.

- Foi assim que sempre se fez. A literatura é a literatura, seu Paulo. A gente discute, briga, trata de negócios naturalmente, mas arranjar palavras com tinta é outra coisa. Se eu fosse escrever como falo, ninguém me lia. (RAMOS, 2018, p. 9, grifos nossos) 
Por esse tipo de comportamento, do qual Padilha também é alvo várias vezes no romance, percebe-se também que o coronel, além de dominar as personagens intelectuais, humilhava-as constantemente de modo a reafirmar seu mando. Evidentemente, uma personagem rotineiramente humilhada por outra poderia nutrir um grande ressentimento ao longo dos anos. Porém, há, para além da humilhação, um elemento que particulariza e intensifica o ressentimento de Luís Padilha. Esse elemento é o coronel, de maneira eticamente questionável, ter-lhe tomado a fazenda. Inclusive, é a isso que Paulo Honório atribui a radical mudança ideológica de Padilha, tanto que faz questão de frisar como o professor passou a manifestar "ideias sanguinárias" e a pregar, “cochichando, o extermínio dos burgueses" (RAMOS, 2018, p. 60) apenas depois de ter sido alienado de sua herança.

Nesse sentido, são fundamentais as considerações de Carlos Nelson Coutinho sobre o que Padilha representa no romance. Para Coutinho (2011, p. 163), essa personagem encarnaria o recalque e a frustração como bases para uma aceitação ainda abstrata do socialismo por parte de setores da classe média. Sendo recalque e frustração dois ingredientes primordiais para o surgimento do ressentimento, isso torna mais evidente que, por motivos diferentes dos de Iago em Otelo, Luís Padilha também é um ressentido e tem motivos talvez até mais fortes do que os do alferes para desejar vingança. Afinal, enquanto Iago apenas havia sido preterido em uma promoção que poderia se concretizar em outra oportunidade dada a confiança do mouro nele, Luís Padilha havia sido, em certo sentido, "roubado" por Paulo Honório. Em outras palavras, enquanto Otelo não atentou efetivamente contra a dignidade e os bens de Iago, Paulo Honório tomou bens de Padilha para ascender socialmente, achincalhando-o constantemente para demonstrar seu poder sobre ele.

Além disso, sendo Paulo Honório e Padilha pai coronéis, podemos supor que o ressentimento de Padilha filho pela perda de S. Bernardo estaria calcado em outra questão além da financeira: a disputa pelo poder político. Para justificar isso, recorremos à explicação de Victor Nunes Leal em Coronelismo, Enxada e Voto (2012) sobre o coronelismo enquanto fenômeno político brasileiro e, principalmente, sobre os “direitos" dos coronéis em suas esferas de influência: 
social dos chefes locais, notadamente dos senhores de terras. [...] Dentro da própria esfera de influência, o coronel como que resume em sua pessoa, sem substituí-las, importantes instituições sociais. Exerce, por exemplo, uma ampla jurisdição sobre seus dependentes, compondo rixas e desavenças e proferindo, às vezes, verdadeiros arbitramentos, que os interessados respeitam. Também se enfeixam em suas mãos, com ou sem caráter oficial, extensas funções policiais, de que frequentemente se desincumbe com a sua pura ascendência social, mas que eventualmente pode tornar efetivas com o auxílio de empregados, agregados ou capangas. (LEAL, 2012, p. 43-45)

Ou seja, ao vender S. Bernardo para Paulo Honório, Luís Padilha perde uma fonte de renda e o prestígio da posição de coronel herdada do pai, mas, principalmente, a possibilidade de ser, no futuro, o grande jogador político da região no lugar de Mendonça, à época o homem forte de Viçosa. Sendo assim, é possível que, ao contrário do que Paulo Honório afirma no capítulo IV (RAMOS, 2018, p. 28), a fonte do desejo de Padilha de permanecer dono de S. Bernardo não fosse a estima pela fazenda, mas a consciência de quanto poder e prestígio obteria se os ventos começassem a soprar a seu favor nos negócios. No entanto, essas expectativas são destruídas, e, pior ainda, Padilha também passa a sofrer o rígido controle exercido por Paulo Honório sobre todos em sua esfera de influência - após o assassinato de Mendonça, toda a região de Viçosa.

Outro ponto importante é que o controle de Paulo Honório sobre as outras personagens não significa que, em alguns momentos, o latifundiário não se engane, pelo menos em partes, quanto ao caráter ou às convicções delas. Um desses casos, em nosso entendimento, é o de Luís Padilha, o que torna a situação dessa personagem, mais uma vez, parecida com a de Iago em Otelo. Esse erro de julgamento é expresso no romance de maneira muito similar à tragédia shakespeariana. Afinal, se em Otelo o comandante das tropas venezianas qualifica Iago como "honesto", Padilha é sempre retratado como o mesmo rapaz ingênuo e boêmio do capítulo IV.

Entretanto, como procuraremos demonstrar a partir de agora, assim como o "honesto" Iago se vinga de Otelo destruindo sua vida conjugal com Desdêmona e roubando-lhe a felicidade e a ordem - parafraseando Dezan (2001) -, a vingança do “ingênuo" Luís Padilha ultrapassa a cooptação de uma dúzia de empregados de Paulo Honório para a causa revolucionária ao final do romance. Na verdade, Padilha, tão conhecedor do sentimento de propriedade de Paulo Honório quanto Iago do sentimento de inferioridade de Otelo, é responsável direto por fazer surgir o ciúme que faria o coronel, à sua maneira, "asfixiar” Madalena. Resta-nos, então, comparar as trajetórias dos dois subordinados que se insurgem contra seus patrões. 


\section{LUÍS PADILHA, O IAGO DE S. BERNARDO?}

Dadas as possíveis motivações de Luís Padilha para atuar como o Iago de $S$. Bernardo - as constantes humilhações a que Paulo Honório o submetia e o fato de o coronel tê-lo alienado de sua herança e dos possíveis benefícios financeiros e políticos vindos dela - e a semelhança de caráter entre ambos, que podem ser interpretados como intelectuais ressentidos em busca de vingança, resta-nos demonstrar como Padilha vai contribuindo para fazer surgir o ciúme em Paulo Honório e em que essa construção se assemelha ou difere da de Iago em relação a Otelo.

Nosso primeiro passo é comparar a relação de Padilha e Madalena com a de Iago e Desdêmona. Lembramos que, enquanto ao alferes cabe acusar Desdêmona de adultério com o tenente Cássio, o professor está, na verdade, na posição de acusado de adultério, pois a grande suspeita de Paulo Honório, revelada no capítulo XXIV, é a de que Padilha seria ao mesmo tempo amante de sua esposa e comparsa dela em um complô comunista para reduzi-lo à miséria. Ou seja, enquanto Iago manipula Otelo de fora do suposto triângulo amoroso, Luís Padilha exerce sua manipulação sendo considerado uma das pontas desse triângulo. Além disso, frisamos também que, ao contrário do que acontece com Desdêmona e Iago em Otelo, a relação entre Madalena e Luís Padilha altera-se sensivelmente ao longo dos capítulos de S. Bernardo. Enquanto a esposa do mouro sempre expressa opiniões positivas sobre Iago - e isso não muda, porque ela é assassinada por Otelo antes de saber da influência do alferes em tudo o que lhe vinha ocorrendo -, Madalena inicialmente enxerga em Padilha, como Paulo Honório revela no capítulo XVII, "uma alma baixa” (RAMOS, 2018, p. 110). Entretanto, posteriormente passa a conversar com o professor de S. Bernardo com muita frequência, aparentando uma contradição que o coronel, inclusive, faz questão de frisar no capítulo XXIII, exatamente anterior àquele em que o ciúme vem à tona. Nota-se também que o motivo literário “conspiração" já se manifesta nas palavras do coronel:

D. Glória sempre com segredinhos ao ouvido de seu Ribeiro. E Madalena escutando o Padilha. O Padilha, que tinha uma alma baixa, na opinião dela. Para o inferno. Tão bom era um como o outro. Entretidos, animados. Conspiração. Talvez não fosse nada. Mas para quem, como eu, andava com a pulga atrás da orelha! Aborrecia. (RAMOS, 2018, p. 142) 
A grande questão, porém, é saber os sentimentos de Padilha em relação a Madalena. Afinal, enquanto envenenava Otelo contra Desdêmona e Cássio, Iago chega a confessar que se sentia atraído pela esposa do chefe: “[...] amar eu também a amo, não por um puro desejo carnal... muito embora por vezes eu me veja cometendo um tão grande pecado[...]" (SHAKESPEARE, 2017, p. 56). Que sentimentos, então, podemos detectar entre as duas personagens graciliânicas?

No primeiro capítulo em que a moça é mencionada, o IX, ela é alvo de conversas de alguns amigos do coronel, entre eles Padilha, que "não achou qualidade que se comparasse aos peitos e às pernas" (RAMOS, 2018, p. 53). Em nenhum momento, no entanto, Luís Padilha fala em sentir qualquer tipo de afeto pela normalista, ou, pelo menos, Paulo Honório não reproduz falas do professor nesse sentido. Disso, podemos inferir com razoável certeza que, pelo menos em um primeiro momento, se confiarmos no relato de Paulo Honório, o interesse ali era plenamente físico. Inclusive, vale registrar que o coronel não fica sabendo da atuação intelectual de Madalena graças a Padilha, mas a Azevedo Gondim, o que, a nosso ver, é mais um indício de que, pelo menos inicialmente, o interesse de Padilha por Madalena, se existia, era apenas carnal.

Curiosamente, a maior parte das conversas entre Madalena e Padilha estão situadas fora da narrativa. Aliás, o único diálogo em que ambos participam ao mesmo tempo dentro do romance e têm suas falas reproduzidas por Paulo Honório é o que desencadeia o ciúme, no capítulo XXIV, durante o jantar de comemoração de dois anos de casamento entre o coronel e a normalista. Ali, a moça mostra-se mais simpática a uma possível revolução no Brasil do que o seu cônjuge esperava. Durante essa conversa, em especial quando Madalena defende a revolução (abstratamente), quem vocaliza apoio a ela é o próprio Luís Padilha:

— Você também é revolucionária? exclamei com mau modo.

— Estou apenas perguntando por quê.

- Ora por quê! Porque o crédito se sumia, o câmbio baixava, a mercadoria estrangeira ficava pela hora da morte. Sem falar na atrapalhação política.

- Seria magnífico, interrompeu Madalena. Depois se endireitava tudo.

- Com certeza, apoiou Luís Padilha.

— Vocês sabem o que estão dizendo? (RAMOS, 2018, p. 151)

Apesar de este apoio poder ser interpretado exclusivamente como uma demonstração do entusiasmo do professor com a causa revolucionária, é importante lembrar novamente que, no capítulo XI, ele e Marciano quase são expulsos de S. 
Bernardo depois de serem flagrados por Paulo Honório em uma conversa exaltada sobre o fim do latifúndio, uma causa comumente associada a revolucionários. A menos que Luís Padilha fosse totalmente incapaz de entender os outros, não seria crível ele não compreender, a partir desse episódio, o quanto seu patrão abominava o ideal revolucionário exatamente porque uma revolução no mundo ficcional de S. Bernardo ameaçaria a condição de Paulo Honório como homem influente em Viçosa e, principalmente, como proprietário de terras. Retomando Candido (1992), a revolução ameaçaria sua essência como personagem, o sentimento de propriedade.

Além disso, conhecedor do caráter brutal do coronel, Luís Padilha também é personagem fundamental em outro capítulo bastante significativo do romance, o XXI, em que Paulo Honório e Madalena discutem por causa das agressões do protagonista a Marciano logo após uma conversa deste com o professor. Não tendo sido tirado de cena quando o casal começa a discutir, pode-se presumir que, além de ter contribuído indiretamente para Marciano ser violentado, Padilha ouviu a discussão em parte ou na íntegra. Novamente, a menos que o ex-proprietário de S. Bernardo fosse absolutamente incapaz de entender o mundo a seu redor, ele teria percebido com alguma facilidade o conflito de valores entre marido e esposa naquele momento, podendo utilizar-se disso em seu benefício quando necessitasse ou desejasse. Em outras palavras, a nosso ver, o apoio de Luís Padilha à "revolucionária" Madalena durante a conversa do capítulo XXIV seria, além de um discurso revolucionário fervoroso, um indício de ele ter percebido e estar usando o "sentimento de propriedade" (CANDIDO, 1992) de Paulo Honório contra o casal, assim como Iago percebera o "sentimento de inferioridade" (POLIDÓRIO, 2013) de Otelo e se utilizara dele para envenená-lo contra Desdêmona.

No caso de Padilha, evidentemente, isso é menos perceptível porque, enquanto o alferes protagoniza a tragédia shakespeariana e anuncia a todo tempo suas intenções ao leitor/espectador, o professor é uma personagem secundária cujas falas são reproduzidas pelo narrador Paulo Honório. Há, no entanto, pelo menos outros dois indícios que nos permitiriam atribuir a Padilha o título de "o Iago de $S$. Bernardo" mesmo com a diferença de importância entre os dois em seus respectivos mundos ficcionais. $O$ primeiro indício também está no capítulo XXIV e mantém relação com o jantar de dois anos de casamento entre Paulo Honório e Madalena. Mais cedo naquele dia, o professor colhia flores no jardim. Sendo confrontado pelo coronel, por estar se desviando de suas 
atribuições, Luís Padilha alega só estar seguindo ordens de Madalena, o que leva Honório a reclamar das frequentes conversas entre o professor e a normalista. A isso, o professor responde: "E quanto às conversas, seu Paulo compreende. Uma senhora instruída meter-se nestas bibocas! Precisa uma pessoa com quem possa entreter de vez em quando palestras amenas e variadas" (RAMOS, 2018, p. 148).

Essa fala de Padilha afeta Paulo Honório tão profundamente que, no próprio capítulo XXIV e nos seguintes, a expressão "palestras amenas e variadas" reaparece várias vezes na boca (ou melhor, na pena) do coronel. Isso ressalta, ironicamente, um sentimento não de propriedade, mas de inferioridade que sente - o mesmo que, segundo Polidório (2013), Otelo teria em relação a Cássio e Desdêmona - por não ter o vocabulário nem as outras habilidades intelectuais da esposa e do próprio Padilha. Aliás, quando Paulo Honório formula pela primeira vez a acusação de "comunista" e "materialista" contra Madalena, ainda no capítulo XXIV, logo após a moça defender abstratamente a revolução e Padilha a apoiar, aparece justamente a expressão "palestras amenas e variadas": "Comunista, materialista. Bonito casamento! Amizade com o Padilha, aquele imbecil. 'Palestras amenas e variadas'. Que haveria nas palestras? Reformas sociais, ou coisa pior. Sei lá!” (RAMOS, 2018, p. 155, grifos nossos). Nesse contexto, questionamos novamente: teria sido o apoio de Padilha à fala de Madalena sobre a revolução mero furor de um militante ou esse apoio poderia ser parte da estratégia desse intelectual ressentido para minar a relação do casal?

Por fim, o segundo indício de uma possível premeditação de Padilha contra Paulo Honório e Madalena está no capítulo XXVII, em que o coronel, já enciumado, demite o professor como retaliação à imaginada traição-complô dele com a moça. Na verdade, como explicaremos, são dois indícios que se conjugam para formar um maior. Depois de apontar, coerentemente, que Paulo Honório não teria nenhum motivo evidente para demiti-lo, Padilha coloca Madalena como motivo de sua demissão, dando ensejo ao seguinte diálogo:

— Ó Padilha, por que foi que você disse que Madalena era a causa da sua desgraça?

- E o senhor quer negar? Se não fosse ela, eu não perdia o emprego. Foi ela. E, veja o senhor, eu não gostava daquilo. Muitas vezes opinei, sem rebuço: "D. Madalena, seu Paulo embirra com o socialismo. É melhor a senhora deixar de novidade. Essas conversas não servem.” Está aí. Papagaio come milho, periquito leva a fama. O periquito sou eu.

Fraquejei: 
- Que diabo discutiam vocês?

O meu ciúme tinha-se tornado público. Padilha sorriu e respondeu, hipócrita:

- Literatura, política, artes, religião... Uma senhora inteligente, a d.

Madalena. E instruída, é uma biblioteca. Afinal eu estou chovendo no molhado. O senhor, melhor que eu, conhece a mulher que possui. (RAMOS, 2018, p. 172-173, grifos nossos)

Primeiro, Luís Padilha demonstra de vez entender perfeitamente como o patrão pensa, pois, para se proteger e aumentar o ciúme de Paulo Honório, culpa Madalena por seu infortúnio e alega tê-la aconselhado a parar com o socialismo. Aparentemente, isso seria uma última manobra desesperada do professor para tentar manter o emprego e a estadia em S. Bernardo, mas, se fosse apenas essa sua intenção ao longo do romance, por que ele a teria apoiado quando ela demonstrou, abertamente, alguma simpatia à revolução? Além disso, no capítulo XXI, o da discussão entre o casal por causa das agressões a Marciano, Padilha age de modo muito parecido quando confrontado por Paulo Honório sobre suas conversas com Marciano e também alega ter aconselhado o funcionário a se portar como o patrão desejaria. Em outras palavras, por que atribuir a essa intervenção desesperada de Padilha no capítulo XXVII apenas a intenção de autopreservação se ele rotineiramente fazia um jogo duplo de defender ideias revolucionárias enquanto servia a Paulo Honório, justamente aquele que lhe tomara a sua herança?

A outra parte desse indício final, nesse sentido, fortalece nossa hipótese de uma possível premeditação por parte de Luís Padilha. Afinal, sua última frase, não por acaso, não é "o senhor, melhor que eu, conhece a mulher com quem se casou" ou algo nesse sentido. O professor usa o verbo possuir, que, por definição, está ligado à propriedade e ao sentimento que constitui Paulo Honório. Porém, tal como Otelo demonstra não conhecer Desdêmona tão bem quanto deveria, também Paulo Honório admite só ter começado a compreender Madalena depois de ela ter cometido suicídio. Ou seja, o coronel, na verdade, não conhecia a própria esposa, o que fez seu ciúme se tornar incontrolável justamente a partir do capítulo XXVII e dessa fala de Padilha. Com isso, insistimos: não nos parece que seria absolutamente impensável o intelectual ressentido de S. Bernardo, tal como o de Otelo, ter vislumbrado a vingança contra seu patrão ao perceber na relação conjugal um possível (e, no caso de Paulo Honório e Madalena, quase inevitável) desencadeador da desordem - parafraseando Dezan (2001) - na vida dele. 


\section{CONSIDERAÇÕES FINAIS}

Ao longo de nosso artigo, procuramos demonstrar que, no mínimo, mesmo Iago sendo caracterizado como um manipulador muito mais hábil e ostensivo do que Luís Padilha, em termos de caráter e de motivação, a personagem de Graciliano Ramos cumpre os requisitos que possibilitam com que seja considerada a versão de Iago em $S$. Bernardo: ambos eram intelectuais ressentidos e tinham motivos para querer vingança contra seus patrões. Aliás, poderíamos até questionar se a motivação do professor não era mais forte do que a do alferes, pois, enquanto Iago apenas tinha sido preterido pontualmente em uma promoção, mas era constantemente elogiado por Otelo, Luís Padilha tinha sido, de certa maneira, "roubado" por Paulo Honório e, pior ainda, submetido a constantes humilhações, principalmente depois de ter-se tornado funcionário do coronel.

Em face disso, esperamos ter instigado o debate sobre a possibilidade de comparação entre o professor revolucionário Luís Padilha, de S. Bernardo, de Graciliano Ramos, e o alferes Iago, de Otelo, de William Shakespeare, em especial porque raras são as análises da crítica graciliânica que se concentram com mais profundidade em outras relações do que a de Paulo Honório e Madalena.

Tendo em vista que este artigo surgiu da indagação de um crítico, desejamos encerrá-lo legando outro questionamento: mesmo sem se atribuir a Luís Padilha o título de "Iago de S. Bernardo", seria totalmente impensável defender que o professor, tal como o alferes, continuou subordinado a seu patrão também "para dar-lhe o troco que merece [merecia]" (SHAKESPEARE, 2017, p. 14)? A nosso ver, as evidências expostas levam-nos a suspeitar que não, em especial porque, independentemente da influência de Padilha no desfecho catastrófico de Madalena, o fato de ele ter arregimentado os homens de Paulo Honório para a causa revolucionária que o faria perder de vez o posto de mais influente força política na região de Viçosa seria, de certa maneira, um "troco merecido".

\section{Referências}


BLOOM, Harold. Othello. In: BLOOM, Harold. Shakespeare: the invention of the human. New York: Riverhead Books, 1998. p. 432-475.

CANDIDO, Antonio. Ficção e confissão: ensaios sobre Graciliano Ramos. São Paulo: Editora 34, 1992.

COUTINHO, C. N. Graciliano Ramos. In: COUTINHO, Carlos Nelson. Cultura e sociedade no Brasil: ensaios sobre ideias e formas. 4. ed. São Paulo: Expressão Popular, 2011. p. 141-194.

DEZAN, Edimilson. Otelo, de Shakespeare: um casal quase perfeito com uma ameaça satânica e maquiavélica ao lado. UniLetras, Ponta Grossa, v. 23, n. 1, p. 51-69, 2001. Disponível em: https://revistas2.uepg.br/index.php/uniletras/article/view/216/214. Acesso em 08 nov. 2020.

JUAREZ FILHO, Edmundo. História e alegoria em São Bernardo de Graciliano Ramos. 2006. 258f. Dissertação (Mestrado em Letras Clássicas e Vernáculas) Faculdade de Filosofia, Letras e Ciências Humanas, Universidade de São Paulo, São Paulo, 2006. Disponível em: http://www.teses.usp.br/teses/disponiveis/8/8149/tde23082007-133901/pt- br.php. Acesso em 24 abr. 2020.

LAFETÁ, João Luiz. O mundo à revelia (posfácio). In: RAMOS, Graciliano. São Bernardo. Rio de Janeiro/São Paulo: Record, 1995. p. 192-217.

LEAL, Victor Nunes. Coronelismo, enxada e voto: o município e o regime representativo no Brasil. 7 ed. São Paulo: Companhia das Letras, 2012.

LORENÇATO, Arnaldo Marcílio Monteiro. Paulo Honório/Madalena: um contrato de alto risco - análise da adaptação do romance São Bernardo para o cinema. 1994. 242 f. Dissertação (Mestrado em Cinema) - Escola de Comunicação e Artes de São Paulo, Universidade de São Paulo, São Paulo.

POLIDÓRIO, Valdomiro. Análise de algumas características da peça Otelo. Travessias, Cascavel, v. 7, n. 1, p. 225-231, 2013. Disponível em: http://erevista.unioeste.br/index.php/travessias/article/view/6533/6241. Acesso em: 10 nov. 2020.

RAMOS, Graciliano. S. Bernardo. 100 ed. Rio de Janeiro: Record, 2018.

SHAKESPEARE, William. Otelo. Trad. Beatriz Viégas-Faria. Porto Alegre: L\&PM, 2017. 
Uma tentativa de comparação entre as personagens Luís Padilha, de S. Bernardo, de Graciliano Ramos, e Iago, de Otelo, de William Shakespeare

\footnotetext{
${ }^{1}$ No original: "No villain in all literature rivals Iago as a flawless conception, who requires no improvement". Todas as traduções feitas de excertos dessa obra de Bloom (1998) ao longo do artigo são nossas.

${ }^{2}$ No original: "Shakespeare's great male intellectuals (as contrasted to Rosalind and Beatrice, among his women) are only four all together: Falstaff and Hamlet, Iago and Edmund. Of these, Hamlet and Iago are also aesthetes, critical consciounesses of near-preternatural power. Only in Iago does the aesthete predominate, in close alliance with nihilism and sadism."

${ }^{3}$ No original: "There can be no question concerning Iago's primacy in the play: he speaks eight soliloquies, Othello only three".

${ }^{4}$ No original: "We cannot arrive at a just estimate of Othello if we undervalue Iago, who would be formidable enough to undo most of us if he emerged out of his play into our lives. Othello is a great soul hopelessly outclassed in intellect and drive by Iago. [...] The prophet of Resentment, Iago presages Smerdyakov, Svidrigailov, and Stavrogin in Dostoevsky, and all of the ascetics of the spirit deplored by Nietzsche".
} 